\title{
Clinicopathological Studies on the Effect of Carica Papaya on Experimentally Induced Short Term Hyperglycemia in Rats
}

\author{
Mohamed A. Hashem, Shimaa A.A. Ismail and Basma M.A. Al Lithey* \\ Clinical Pathology Department, Faculty of Veterinary Medicine, Zagazig University, \\ Zagazig, Egypt, 44511
}

Article History: Received: 8/11/2018 Received in revised form: 7/12/2018 Accepted: 16/1/2019

\begin{abstract}
The study was designed to evaluate the Carica papaya (C. papaya) effect on diabetes mellitus (DM) and its complications. Ninety, clinically healthy white male rats of two months old $(100 \mathrm{~g}$ average body weight) were divided into equal six groups of 15 rats each. Induction of DM was done by administration of rats by $65 \mathrm{mg} / \mathrm{kg}$ body weight $(\mathrm{BW})$ of streptozotocin (STZ). However, $C$. papaya leaves aqueous extract $(0.11 \mathrm{~g} / \mathrm{mL}$ and $0.22 \mathrm{~g} / 2 \mathrm{~mL})$ were administered to rats for 30 days. Our results revealed that after 15 and 30 days post-STZ injection, aqueous leaves extract of $C$. papaya improved the health status of treated diabetic rats, as serum glucose $(276 \mathrm{mg} / \mathrm{dL}$ to $186.33 \mathrm{mg} / \mathrm{dL})$, fractosamine $(297.44 \mu \mathrm{mol} / \mathrm{L}$ to $272.44 \mu \mathrm{mol} / \mathrm{L})$, total cholesterol (TC) $(139.00 \mathrm{mg} / \mathrm{dL}$ to $121.46 \mathrm{mg} / \mathrm{dL})$, triglycerides (TG) $(197.69 \mathrm{mg} / \mathrm{dL}$ to $179.34 \mathrm{mg} / \mathrm{dL})$, low density lipoprotein-cholesterol (LDL-c) $(47.36 \mathrm{mg} / \mathrm{dL}$ to $20.90 \mathrm{mg} / \mathrm{dL})$, and L-malondialdehyde (MDA) activity $(2.01 \mathrm{nmol} / \mathrm{g}$ tissue to $1.81 \mathrm{nmol} / \mathrm{g}$ tissue) were decreased, while insulin $(1.80$ $\mu \mathrm{IU} / \mathrm{mL}$ to $2.33 \mu \mathrm{IU} / \mathrm{mL}$ ) and high density lipoprotein-cholesterol (HDL-c) levels $(52.10 \mathrm{mg} / \mathrm{dL}$ to $64.69 \mathrm{mg} / \mathrm{dL}$ ) and catalase (CAT) activity $(66.31 \mathrm{U} / \mathrm{g}$ tissue to $71.38 \mathrm{U} / \mathrm{g}$ tissue) were increased when compared with untreated diabetic rats. STZ in the recommended dose induced $\mathrm{DM}$ and there were changes in previous parameters through reactive oxygen species ROS generation and oxidative stress in $\beta$ cell of islet Langerhans in pancreas. It could be concluded that $C$. papaya leaves aqueous extract in doses of $0.11 \mathrm{~g} / \mathrm{mL}$ and $0.22 \mathrm{~g} / 2 \mathrm{~mL}$ has antidiabetic, antihyperlipidaemic and antioxidant effect with protective effect on pancreas and other organs.
\end{abstract}

Key words: Clinical pathology, Diabetes Mellitus, Carica papaya.

\section{Introduction}

Diabetes mellitus (DM) is the most common disorder extend around the world. It is a more complex pathophysiology that is defined as the biochemical abnormalities associated with deviation in glucose metabolism [1]. The biochemical abnormalities caused by diabetes could be observed as hyperglycemia and protein catabolism as energy sources for the body and subsequent dyslipidemia [2]. Chronic hyperglycemia in diabetic cases is accompanied by dysfunction of various body organs especially eyes, kidneys and heart beside, the damage to nerves and blood vessels [3].

Medicinal plants are the spirit of modern drugs, which used all over the world in the daily life to treat various diseases [4]. There are many plants used in the treatment of diabetes, out of them, Carica papaya ( $C$. papaya) which is named as FRUIT OF ANGELS as documented by Christopher Columbus. Various studies revealed that $C$. papaya leaf extract has a role in the treatment of DM due to enhancement of insulin sensitivity as in case of type II diabetes that is characterized by decreasing insulin sensitivity, resulting in insufficient glucose uptake by the cells. Several researches on animals and humans have stated that $C$. papaya leaf extracts could lower the glucose level, and reduce the diabetes complications. Various antioxidants in $C$. papaya leaf extracts are helpful in limiting of other complications of DM such as oxidative stress, kidney damage and fatty liver [5,6]. Herein, the aim of the present study was to evaluate the effects of aqueous extract of $C$. papaya leaves on experimentally induced $\mathrm{DM}$ in rats via 
hematological, biochemical, histopathological and antioxidant parameter.

\section{Materials and Methods}

\section{Plant}

Carica papaya leaves were collected from a native farm in Damietta city, Damietta Governorate, Egypt. Plant leaves were green in color and branched.

\section{Carica papaya leaves processing}

C. papaya leaves were washed in $1 \%$ iodine aqueous solution then distilled water. Then they were dried, cut into pieces then ground using mortar and pestle. Fifty grams of resulting leaves powder were soaked into 450 $\mathrm{mL}$ of distilled water in conical flask with stirring carefully for $8 \mathrm{~min}$, then corked and left for $14 \mathrm{~h}$. The solution was filtered using a Whatman No.1 filter paper and the extract was stored in refrigerator at $4^{\circ} \mathrm{C}$. Each extract containing $0.11 \mathrm{~g} / \mathrm{mL}$ of $C$. papaya leaves [7]. Distilled water and 1\% iodine were purchased from El-Gomhoria Company in Zagazig city, El-Sharkia Governorate, Egypt.

\section{Diabetogenic agent}

Streptozotocin (STZ) (2-deoxy-2-[3methyl-3-nitrosourea] 1-D-glucopyranose), was obtained from El-Gomhoria Company in Zagazig city, El-Sharkia Governorate, Egypt.

\section{Experimental design}

Ninety, clinically healthy white male rats were purchased from Laboratory Animal Housing, Faculty of Veterinary Medicine, Zagazig University. The animals were kept in metal cages and divided into 6 main groups. All animals were kept under hygienic conditions, given balanced ration with water ad-libitum and observed for 10 days before experimentation. Group I $(n=15)$ : comprising rats without treatment as a negative control. Group II $(n=15)$ : including rats with DM which induced in overnight fasted rats by a single intra peritoneal (IP) injection of STZ by a dose of $65 \mathrm{mg} / \mathrm{kg}$ BW freshly dissolved in $0.1 \mathrm{M}$ citrate buffer $(\mathrm{pH} 4.5)$ [8]. Group III $(n=15)$ : rats were received orally a daily dose of $C$. papaya leaves aqueous extract $(0.11$ $\mathrm{g} / \mathrm{mL}$ ) by stomach cannula for 30 days [7]. Group IV $(n=15)$ : rats were administrated orally a daily dose of $C$. papaya leaves aqueous extract as in group III for 40 days. After 10 days post $C$. papaya treatment, the rats were injected by STZ as in group II, followed by completion of $C$. papaya administration. Group V $(n=15)$ : rats with induced DM as previously described in group II were administered $C$. papaya leaves aqueous extract $(0.11 \mathrm{~g} / \mathrm{mL})$ daily by stomach cannula for 30 days. Group VI $(n=15)$ : rats with induced DM as mentioned previously were administered C. papaya leaves aqueous extract $(0.22 \mathrm{~g} / 2 \mathrm{~mL})$ daily by stomach cannula for 30 days. The experimental animals were managed according to the management standards. The experimental study was approved by the Committee of Animal Welfare and Research Ethics, Faculty of Veterinary Medicine, Zagazig University, Egypt.

\section{Sampling}

Blood samples: The blood samples were obtained from the retro-orbital venous plexus of rats at 15 and 30 days post treatment without anticoagulant in sterile test tubes and left till clotting. Serum was separated by centrifugation at $3000 \mathrm{rpm}$ for $15 \mathrm{~min}$. The clear supernatant serum was aspirated gently by Pasteur pipettes. The serum was transferred to dry and labelled eppendorfs for biochemical analysis [9].

Tissue samples: Pancreas samples were collected at each necropsy after 15 and 30 days post treatment. After sacrifice, samples were immediately fixed in $10 \%$ neutral buffered formalin for $48 \mathrm{~h}$ for histopathological investigation. Five-microns thick paraffin sections were prepared, stained by hematoxylin and eosin (H\&E) and then examined microscopically [10]. Also, parts of livers were collected and kept at $-20^{\circ} \mathrm{C}$ till using for antioxidant enzymes determination.

Tissue homogenate: The homogenized liver tissue samples (100 $\mathrm{mg}$ of tissue) were added to $1 \mathrm{~mL}$ of homogenization buffer $(0.1$ $\mathrm{M}$ phosphate buffer, $\mathrm{pH} 7.4$ containing $1 \mathrm{mM}$ EDTA and $0.005 \%$ butylated hydroxytoluene (BHT) (Sigma-Aldrich), then the samples were centrifuged at $8000 \mathrm{rpm}$ for 10 minutes and the supernatants were collected in a clean tube for antioxidant evaluation [11].

\section{Biochemical and antioxidant studies}



fructosamine [14], total cholesterol (TC) [12], triglycerides (TG) [15] and high density lipoprotein (HDL-c) [12] were estimated in the serum. Serum low density lipoprotein cholesterol LDL-c was obtained mathematically [16]. Furthermore, catalase (CAT) activity [17] and malondialdehyde (MDA) level were detected in tissue [18].

\section{Statistical analysis}

The obtained data was statistically analyzed using one way ANOVA according to Tamhans and Dunlop [19] using MSTAT-C computer program. The differences among the groups

test. Values were considered statistically significant when $\mathrm{p}<0.05$.

\section{Results and Discussion}

All studies now are looking for natural substances used in the effective treatment of diabetes and its complication. There are several natural compounds that can reduce the activity of some enzymes shared in glucose metabolism, and other enzymes decrease the insulin action [20]. Other researches have stated that some compounds found in plants can modulate $\beta$-cell apoptosis and stimulate the action of insulin [21].

Table 1: Diabetic markers of rats in different groups at 15 and 30 days post treatment $(n=5$, mean $\pm S E)$.

\begin{tabular}{|c|c|c|c|c|c|c|}
\hline Time of sampling & & 15 days & & & 30 days & \\
\hline $\begin{array}{l}\text { Parameters } \\
\text { Groups }\end{array}$ & $\begin{array}{l}\text { Glucose } \\
(\mathrm{mg} / \mathrm{dL})\end{array}$ & $\begin{array}{l}\text { Insulin } \\
(\mu \mathrm{IU} / \mathrm{mL})\end{array}$ & $\begin{array}{c}\text { Fructosamine } \\
(\mu \mathrm{mol} / \mathrm{L})\end{array}$ & $\begin{array}{l}\text { Glucose } \\
(\mathrm{mg} / \mathrm{dL})\end{array}$ & $\begin{array}{l}\text { Insulin } \\
(\mu \mathrm{IU} / \mathrm{mL})\end{array}$ & $\begin{array}{r}\text { Fruct } \\
(\mu \mathrm{n}\end{array}$ \\
\hline Gp (I) & $111.67 \pm 3.28^{\mathrm{c}}$ & $2.67 \pm 0.41^{\mathrm{a}}$ & $250.42 \pm 48.74^{b}$ & $103.00 \pm 1.52^{\mathrm{c}}$ & $2.95 \pm 0.40^{a b}$ & $240.00 \pm 15.59^{b}$ \\
\hline Gp (II) & $510.00 \pm 40.4^{\mathrm{a}}$ & $0.95 \pm 0.02^{c}$ & $390.87 \pm 4.88^{\mathrm{a}}$ & $650.00 \pm 0.01^{\mathrm{a}}$ & $0.86 \pm 0.02^{\mathrm{d}}$ & $445.33 \pm 41.88^{\mathrm{a}}$ \\
\hline Gp (III) & $104.00 \pm 2.08^{c}$ & $2.83 \pm 0.21^{\mathrm{a}}$ & $244.00 \pm 12.39^{\mathrm{b}}$ & $100.00 \pm 0.57^{\mathrm{c}}$ & $3.26 \pm 0.15^{\mathrm{a}}$ & $241.55 \pm 11.65^{b}$ \\
\hline Gp (IV) & $201.67 \pm 38.5^{b}$ & $1.94 \pm 0.22^{\mathrm{b}}$ & $296.38 \pm 5.19^{b}$ & $181.00 \pm 24.63^{\mathrm{b}}$ & $2.36 \pm 0.29^{\mathrm{bc}}$ & $270.70 \pm 15.49^{b}$ \\
\hline $\mathrm{Gp}(\mathrm{V})(0.11 \mathrm{~g})$ & $283.67 \pm 12.2^{\mathrm{b}}$ & $1.79 \pm 0.09^{\mathrm{b}}$ & $305.77 \pm 11.54^{\mathrm{b}}$ & $206.67 \pm 14.24^{\mathrm{b}}$ & $2.05 \pm 0.08^{\mathrm{c}}$ & $283.00 \pm 37.35^{\mathrm{b}}$ \\
\hline $\mathrm{Gp}(\mathrm{VI})(0.22 \mathrm{~g})$ & $276.00 \pm 25.5^{b}$ & $1.80 \pm 0.15^{\mathrm{b}}$ & $297.44 \pm 14.66^{\mathrm{b}}$ & $186.33 \pm 16.69^{b}$ & $2.33 \pm 0.26^{\mathrm{bc}}$ & $272.44 \pm 35.04^{b}$ \\
\hline
\end{tabular}

- Means in the same column characterized by different letters were statistically significant at $\mathrm{P}<0.05$ and the highest values were marked with the letter (a).

Gp (I): control, Gp (II): diabetic group, Gp (III): C. papaya group, Gp (IV): prophylactic group, Gp (V): treatment group $(0.11 \mathrm{~g}), \mathrm{Gp}(\mathrm{VI})$ : treatment group $(0.22 \mathrm{~g})$

Concerning to diabetic markers evaluation in our study, administration of STZ to rats showed a significant increase in serum glucose and fructosamine levels while serum insulin showed hypo-insulinemia in diabetic rats of group II when compared with the control as shown in Table 1 . These results may be attributed to that STZ destroys pancreatic $\beta$ cells leading to DM. Streptozotocin induces DM by free radical generation which causes a massive reduction in insulin secretion from beta cells of islets of Langerhans, which result in decrease in endogenous release of insulin and the destruction of beta cells may occur via oxidative stress, that increased the level of reactive oxygen species (ROS) in beta cells resulting in oxidative damage to DNA leading to DNA strand breaks [22]. Fructosamine is considered a reflection to glycemic control. It is a stable compound produced by glucose reacts non-enzymatically with amino groups on proteins, so it increased in DM. Also, it can undergo oxidative cleavage resulting in Advanced Glycation End products formation (AGEs), which contributed in long term DM complication [23]. Also, another experiment induction of diabetes in male albino rats by IP injection of STZ (solution prepared in $100 \mathrm{Mm}$ citrate buffer $(\mathrm{pH} \mathrm{4.5)}$ at a dose of $60 \mathrm{mg} / \mathrm{kg}$ BW) showed a significant increase in fasting blood sugar (FBS) and fructosamine and significant reduction in insulin [24]. While our results were partial agree with Amat-alrazaq [25] who stated that feeding of rats on high fat feed diet (HFFD) followed by injection with freshly prepared STZ in citrate buffer (35 $\mathrm{mg} / \mathrm{kg}$, IP, single dose), resulted in persistent blood glucose levels between $200-350 \mathrm{mg} / \mathrm{dL}$, hyperinsulinemia, and hyperlipidemia one week after STZ administration. The animals 
were considered diabetic/ insulin-resistant, after 4 weeks. Diabetic rats showed an increase in fasting blood glucose (FBG) and fructosamine level, due to difference in dose and duration of treatment. Our results disagree with Henderson [26] who reported a nonsignificant change in fructosamine in diabetic patients who received $150 \mathrm{mg}$ of anthocyanins for 3 months when compared with the control and this may be due to difference in duration of experiment and doses of flavonoid used. Histopathological results confirmed the findings in diabetic animals as pancreatic tissue in group II showed degenerative and necrotic changes with vacuolar degeneration of the cells of islets of Langerhans particularly $\beta$ cells and marked atrophy in the pancreatic islets of Langerhans with complete necrosis and disappearance to large numbers of islets of Langerhans (Figure 1A).
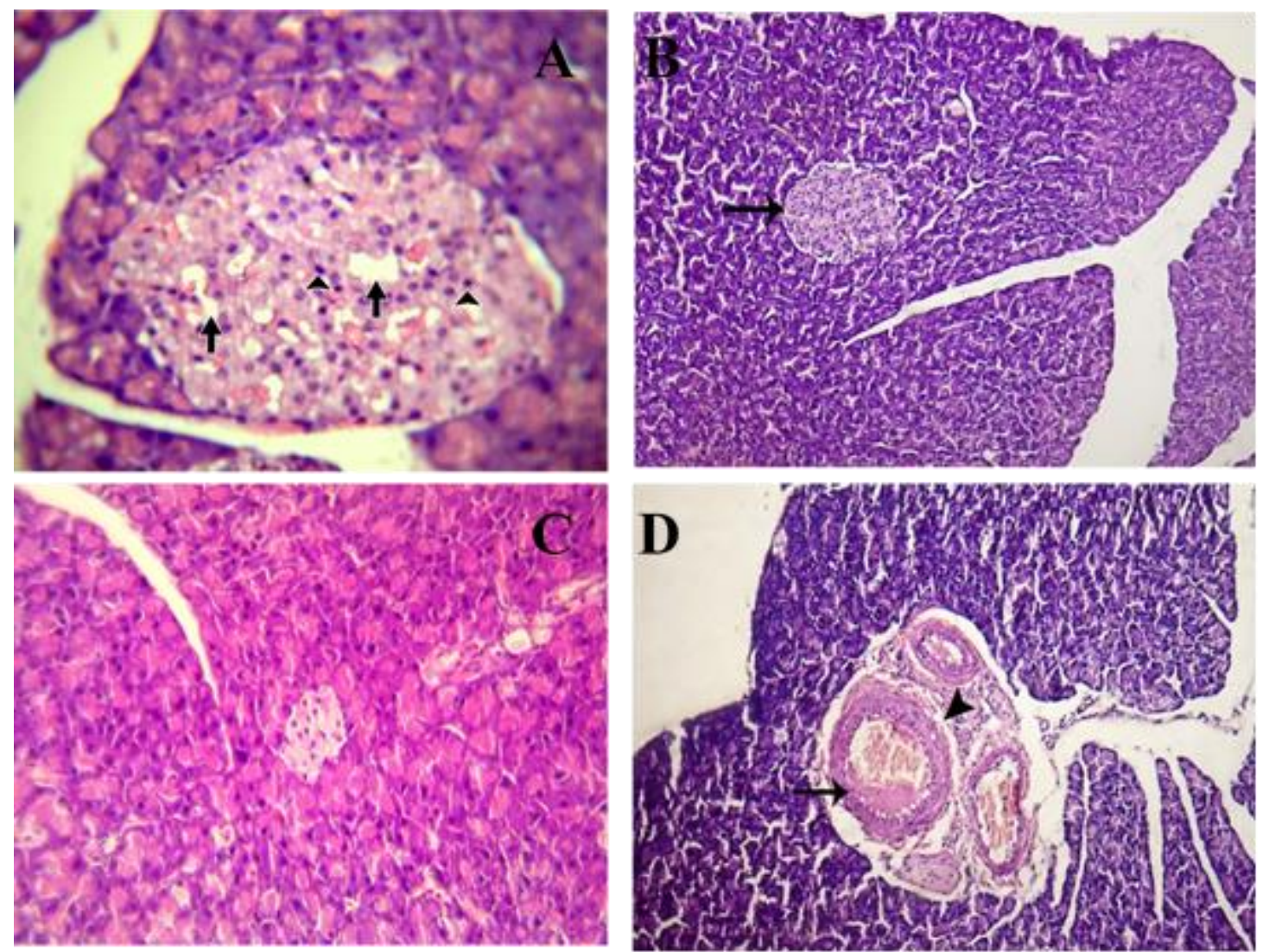

Figure 1: A: Pancreas of rats in diabetic group II, showing vacuolar degeneration of the cells of islets of Langerhans after 15 days post STZ injection, (H\&E) X400. B: Pancreas of rats in C. papaya group (III), showing normal histological structures and architectures, (H\&E) X100. C: Pancreas of rats in treatment group (V), showing atrophy to large percentage of the islets of Langerhans after 15 days post STZ injection, (H\&E) X400. D: Pancreas of rats in prophylactic group (IV), showing vascular congestion after 30 days post STZ injection, (H\&E) X100.

In the current study, C. papaya has a role in improvement the picture of DM when administrated as a prophylactic (group IV) or as treatments (groups V and VI). A significant reduction in glucose and fructosamine levels, with a significant increase in insulin level were observed when compared with diabetic group II after 30 days post STZ injection as shown in Table 1. The hypoglycemic effect of $C$. papaya leaves extract may be caused by inhibition of fatty acid synthesis and decreased of cholesterogenesis [27]. The treatment of diabetic animals by the extract of $C$. papaya 
leaves, lead to significant improvement in blood glucose level due to increase the numbers of functional $\beta$ cell in islets of pancreas [5], and the reduction in rate of intestinal glucose utilization or an increase in peripheral glucose utilization [28,29]. Hii and Howell [30] explained the anti-hyperglycemia effect of flavonoids (present in $C$. papaya leaves extract) as they enhance the insulin secretion from pancreatic islet cells due to its action through changing in $\mathrm{Ca}^{2+}$ fluxes and cyclic nucleotide metabolism. Moreover, there is a prophylactic effect of flavonoids on pancreatic cell as keep on the integrity of cells [31]. According to the results of another experiment, administration of 50, 150 and 300 $\mathrm{mg} / \mathrm{kg} \mathrm{BW}$ of ethanol leaves extracts orally to diabetic mice for 10 days, lead to a significant reduce in serum glucose level and a significant increase in serum insulin level [6]. Also, the hypoglycemic effect of $C$. papaya seeds extract may be either caused by stimulation of insulin secretion from the $\beta$ cells of pancreas or may be due to increase of tissue uptake of glucose [22]. The aqueous $C$. papaya leaves extract stimulate the survived $\beta$ cells with enhancement of more insulin secretion, instead of pointing to the regeneration of $\beta$ cells of the islets as responsible for the insulin secretion and that was agree with our discussion [32]. While other studies [33-35] suggested that the administration of plant extracts contained flavonoids to diabetic rats helped in cell regeneration and restoration of islet size by producing cell hyperplasia.

The histopathological results confirmed the biochemical results; Pancreas of rats in $\mathrm{C}$. papaya group (III), showing normal histological structures and architectures (Figure 1B), Pancreas of rats in treatment group (V), showing atrophy to large percentage of the islets of Langerhans after 15 days post STZ injection (Figure 1C), while prophylactic group (group IV) showed very mild to moderate degenerative and necrotic changes in the form of slight vacuolation of the cells of some islets of Langerhans, and mild atrophy of other islets of Langerhans (Figure1D).

Diabetes Mellitus is a metabolic disease accompanied by hyperlipidemia which may be due to impaired lipolytic hormones action on fat depots [36] which may lead to atherogenesis and cardiac vascular disease (CVD) [37]. The present study showed a significant increase in serum TC, TGs and LDL-c levels and a significant decrease in HDL-c in diabetic rats (group II) when compared with the control after 15 and 30 days post STZ injection as shown in Tables $2 \& 3$. The hyperlipidemia may be due to increase of free fatty acid (FFA) mobility from peripheral depots [38], and decrease removal or increase production or both of one or more lipoproteins [39]. Also, reduction in serum HDL-c level which is the carrier of cholesterol to liver for metabolization, is a predisposing factor to dyslipidemia and atherosclerosis. Insulin deficiency or resistance may be the reason of dyslipidemia, as insulin inhibits the action of HMG-COA (3-hydroxy-3-methyl glutaryl coenzyme A reductase) which is responsible for LDL-c metabolism [40].

Table 2: Lipid profile of rats in different groups at 15 days post treatment $(n=5$ mean $\pm S E)$.

\begin{tabular}{|c|c|c|c|c|}
\hline Parameters & $\begin{array}{c}\text { Total cholesterol } \\
(\mathrm{mg} / \mathrm{dL})\end{array}$ & $\begin{array}{l}\text { Triglycerides } \\
\quad(\mathrm{mg} / \mathrm{dL})\end{array}$ & $\begin{array}{l}\text { LDL-C } \\
(\mathrm{mg} / \mathrm{dL})\end{array}$ & $\begin{array}{l}\text { HDL-C } \\
(\mathrm{mg} / \mathrm{dL})\end{array}$ \\
\hline \multicolumn{5}{|l|}{ Groups } \\
\hline Gp (I) & $118.4 \pm 2.38^{c}$ & $140.74 \pm 11.52^{c}$ & $15.23 \pm 2.16^{b}$ & $75.04 \pm 2.01^{\mathrm{a}}$ \\
\hline$\overline{\mathrm{Gp}(\mathrm{II})}$ & $146.65 \pm 3.20^{\mathrm{a}}$ & $243.45 \pm 12.02^{\mathrm{a}}$ & $49.08 \pm 4.20^{\mathrm{a}}$ & $48.87 \pm 0.63^{c}$ \\
\hline Gp(III) & $112.10 \pm 2.76^{c}$ & $135.00 \pm 13.72^{\mathrm{c}}$ & $13.57 \pm 1.88^{b}$ & $71.52 \pm 0.63^{a}$ \\
\hline$\overline{G p(I V)}$ & $135.07 \pm 1.89^{b}$ & $188.32 \pm 9.90^{b}$ & $41.16 \pm 5.37^{\mathrm{a}}$ & $56.24 \pm 1.98^{b}$ \\
\hline $\mathrm{Gp}(\mathrm{V})(0.11 \mathrm{~g})$ & $140.77 \pm 3.20^{\mathrm{ab}}$ & $199.80 \pm 3.51^{b}$ & $48.80 \pm 3.78^{\mathrm{a}}$ & $52.00 \pm 2.54^{\mathrm{bc}}$ \\
\hline$\overline{\mathrm{Gp}(\mathrm{VI})(0.22 \mathrm{~g})}$ & $139.00 \pm 2.20 \mathrm{ab}$ & $197.69 \pm 6.32 \mathrm{~b}$ & $47.36 \pm 2.42 \mathrm{a}$ & $52.10 \pm 1.19 b c$ \\
\hline
\end{tabular}

- Means in the same column characterized by different letters were statistically significant at $\mathrm{P}<0.05$. Gp (I): control, Gp (II): diabetic group, Gp (III): C. papaya group, Gp (IV): prophylactic group, Gp (V): treatment group $(0.11 \mathrm{~g}), \mathrm{Gp}(\mathrm{VI})$ : treatment group $(0.22 \mathrm{~g})$ 
Table 3: Lipid profile of rats in different groups at 30 days post treatment $(n=5$, mean $\pm S E)$.

\begin{tabular}{lcccc}
\hline Proups & $\begin{array}{c}\text { Total } \\
\text { cholesterol } \\
(\mathbf{m g} / \mathbf{d L})\end{array}$ & $\begin{array}{c}\text { Triglycerides } \\
(\mathbf{m g} / \mathbf{d L})\end{array}$ & $\begin{array}{c}\text { LDL-C } \\
(\mathbf{m g} / \mathbf{d L})\end{array}$ & $\begin{array}{c}\text { HDL-C } \\
(\mathbf{m g} / \mathbf{d L})\end{array}$ \\
\hline $\mathrm{Gp}(\mathrm{I})$ & $116.59 \pm 1.95^{\mathrm{bc}}$ & $145.58 \pm 12.49^{\mathrm{bc}}$ & $15.60 \pm 1.77^{\mathrm{b}}$ & $71.85 \pm 2.10^{\mathrm{a}}$ \\
\hline $\mathrm{Gp}(\mathrm{II})$ & $167.72 \pm 7.90^{\mathrm{a}}$ & $243.68 \pm 11.79^{\mathrm{a}}$ & $69.82 \pm 6.05^{\mathrm{a}}$ & $49.16 \pm 0.26^{\mathrm{c}}$ \\
\hline $\mathrm{Gp}(\mathrm{III})$ & $107.94^{\mathrm{c}} \pm 0.53$ & $122.00 \pm 1.62^{\mathrm{c}}$ & $10.42 \pm 1.04^{\mathrm{b}}$ & $73.11 \pm 1.23^{\mathrm{a}}$ \\
\hline $\mathrm{Gp}(\mathrm{IV})$ & $124.64 \pm 3.51^{\mathrm{b}}$ & $179.27 \pm 9.75^{\mathrm{b}}$ & $22.49 \pm 1.42^{\mathrm{b}}$ & $66.29 \pm 0.96^{\mathrm{b}}$ \\
\hline $\mathrm{Gp}(\mathrm{V})(0.11 \mathrm{~g})$ & $124.58 \pm 6.28^{\mathrm{b}}$ & $187.05 \pm 11.26^{\mathrm{b}}$ & $22.64 \pm 4.79^{\mathrm{b}}$ & $64.52 \pm 2.34^{\mathrm{b}}$ \\
\hline $\mathrm{Gp}(\mathrm{VI})(0.22 \mathrm{~g})$ & $121.46 \pm 2.93^{\mathrm{bc}}$ & $179.34 \pm 23.71^{\mathrm{b}}$ & $20.90 \pm 5.70^{\mathrm{b}}$ & $64.69 \pm 1.90^{\mathrm{b}}$ \\
\hline
\end{tabular}

- Means in the same column characterized by different letters were statistically significant at $\mathrm{P}<0.05$. Gp (I): control, Gp (II): diabetic group, Gp (III): C. papaya group, Gp (IV): prophylactic group, Gp (V): treatment group $(0.11 \mathrm{~g}), \mathrm{Gp}(\mathrm{VI})$ : treatment group $(0.22 \mathrm{~g})$

Administration of $C$. papaya aqueous leaves extract in groups IV, V and VI showed significant decrease in serum TC, TGs and LDL-c levels and a significant increase in serum HDL-c level when compared with diabetic group II after 30 days post STZ injection as shown in Table 3. ie. There was an improvement in lipid profile after administration of $C$. papaya. The hypolipidemic effect of $C$. papaya may be due to flavonoid action which was one of the components of $C$. papaya. The improvement of serum LDL-c level may be due to decrease of VLDL and enhance hepatic depuration of LDL-c precursors [41]. Also, flavonoids improved TG and TC, as it inhibits HMG-CO reductase $[42,43]$.

Oxidative stress has a serious role in pathogenesis of DM and its complication [44]. It is formed during normal metabolism in the body and is stimulated by the environmental factors and chemicals, that effects on antioxidant status [45]. Scavengers of oxidative stress as CAT may have an effect on decreasing the hyperglycemia in DM, which considered supportive defense against ROS, as hyperglycemia aides in auto-oxidation of glucose and produces free radicals as superoxide that in turn caused lipid peroxidation. The CAT is localized in peroxisomes or micro-peroxisomes, which catalysis decomposition of $\mathrm{H}_{2} \mathrm{O}_{2}$ to water and oxygen, thus protects cell from oxidative damage [46]. With reference to the antioxidant and the lipid peroxidation assessment in the present study, administration of STZ to rats in diabetic group (group. II) showed a significant decrease in hepatic CAT activity when compared with all groups after 15 and 30 days as shown in Table 4, which may be due to depletion of endogenous antioxidants and generation of free radicals which caused by STZ injection [47]. Our results agree with other studies [48-50], in which, induction of DM in Wister rats by a single IP injection of STZ resulted in significant decrease of hepatic CAT activity after 2 months post STZ injection. Meanwhile, the present results disagree with Durdi and Timur [51] as catalase activity in the diabetic rats was increased in compare with the control group after IP injection of rats by STZ $(50 \mathrm{mg} / \mathrm{kg})$, due to enhanced ROS production, so intracellular enzymatic antioxidant tried to fight those free radicals by increasing CAT production. 
Table 4: Antioxidant activities and lipid peroxidation in rats in different groups at 15 and 30 days post treatment $(n=5$, mean $\pm S E)$.

\begin{tabular}{|c|c|c|c|c|}
\hline Time of sampling & \multicolumn{2}{|c|}{15 days } & \multicolumn{2}{|c|}{30 days } \\
\hline Parameters & $\begin{array}{c}\text { MDA } \\
\text { (nmol/g tissue) }\end{array}$ & $\begin{array}{c}\text { CAT } \\
\text { (U/g tissue) }\end{array}$ & $\begin{array}{c}\text { MDA } \\
\text { (nmol/g tissue) }\end{array}$ & $\begin{array}{c}\text { CAT } \\
\text { (U/g tissue) }\end{array}$ \\
\hline Groups & & & & \\
\hline $\mathrm{Gp}(\mathrm{I})$ & $1.90 \pm 0.26^{b}$ & $65.69 \pm 2.59^{b}$ & $1.26 \pm 0.21^{\mathrm{c}}$ & $69.90 \pm 1.37^{b}$ \\
\hline Gp(II) & $3.00 \pm 0.45^{\mathrm{a}}$ & $48.6 \pm 3.17^{\mathrm{c}}$ & $3.50 \pm 0.25^{\mathrm{a}}$ & $50.89 \pm 3.91^{\mathrm{c}}$ \\
\hline Gp(III) & $1.70 \pm 0.26^{b}$ & $77.69 \pm 1.47^{\mathrm{a}}$ & $1.30 \pm 0.15^{\mathrm{c}}$ & $78.08 \pm 1.07^{\mathrm{a}}$ \\
\hline Gp(IV) & $1.96 \pm 0.14^{b}$ & $70.66 \pm 0.33^{b}$ & $1.83 \pm 0.20^{\mathrm{bc}}$ & $73.30 \pm 1.74^{\mathrm{ab}}$ \\
\hline $\mathrm{Gp}(\mathrm{V})(0.11 \mathrm{~g})$ & $2.50 \pm 0.20^{\mathrm{ab}}$ & $66.31 \pm 1.22^{b}$ & $2.36 \pm 0.17^{\mathrm{b}}$ & $71.38 \pm 0.78^{\mathrm{ab}}$ \\
\hline Gp (VI) $(0.22 \mathrm{~g})$ & $2.01 \pm 0.05^{b}$ & $72.09 \pm 1.48^{\mathrm{ab}}$ & $1.81 \pm 0.25^{\mathrm{bc}}$ & $72.17 \pm 1.65^{\mathrm{ab}}$ \\
\hline
\end{tabular}

- Means in the same column characterized by different letters were statistically significant at $\mathrm{P}<0.05$. Gp (I): control, Gp (II): diabetic group, Gp (III): C. papaya group, Gp (IV): prophylactic group, Gp (V): treatment group $(0.11 \mathrm{~g}), \mathrm{Gp}(\mathrm{VI})$ : treatment group $(0.22 \mathrm{~g})$

Carica papaya contains a lot of phytochemicals which act as antioxidant, like vitamins $\mathrm{C}$ and $\mathrm{E}$, lycopene, and beta-carotene. They reduce the depletion of antioxidant enzymes, so they fight oxidative stress [5255]. Administration of C. papaya in groups IV, $\mathrm{V}$ and VI showed a significant increase in hepatic CAT activity when compared with diabetic group (group II) after 30 days post STZ injection that may be due to quench of free radicals by active hydroxyl group, sulfadryl group and thiol group of several amino acids which found in C. papaya [56]. Sadek [57] observed a significant reduction in lipid peroxidation, and enhanced activity of catalase in albino rats administrated $C$. papaya in a dose of $250 \mathrm{mg} / \mathrm{kg} \mathrm{BW}$ for 40 days.

Lipid peroxidation (auto oxidation) is a chain reaction producing a continuous source of free radicals that initiates further peroxidation in the lipid rich membrane of lipoproteins by $\mathrm{ROS}$ like $\mathrm{OH}^{-}$(Hydroxyl radical), $\mathrm{NO}^{-}$. [Nitric oxide radical], $\mathrm{O}^{-}$ [superoxide radical] and $\mathrm{ROO}^{-}$[Peroxyl radical] resulting in generation of lipid peroxidation products like MDA [58]. In our study, diabetic group (group II) showed a significant increase in hepatic MDA level after 15 and 30 days post STZ injection when compared with other groups as shown in Table 4. The increase in MDA may be due to that free radicals which caused lipid peroxidation and changing phospholipids structure lead to accumulation of MDA [59] with diminishing antioxidant activities in tissues [60].
Administration of $C$. papaya in groups IV and VI showed a significant decrease in MDA when compared with diabetic group II postSTZ injection as shown in Table 4. The improvement in MDA levels may be attributed to flavonoids content of $C$. papaya causing a decrease in lipid peroxidation. The reduction in MDA level by action of Inula britannica flower flavonoids (IBFFs) may be due to enhance antioxidant activities and decrease lipid peroxidation [61], also elevation in MDA may be due to vitamin $\mathrm{E}$ which appears to be the most vital free radical-scavenging antioxidants that works through membranes and lipoproteins, which acts as chain-breaking antioxidant that works as prophylactic against Poly Unsaturated Fatty Acids (PUFA) peroxidation by scavenging peroxyl radicals, vitamin $\mathrm{E}$ gives a hydrogen atom to the free radical, gets oxidized itself to a radical [62].

\section{Conclusion}

Streptozotocin (STZ) in a dose of 65 $\mathrm{mg} / \mathrm{kg}$ BW induced DM through ROS generation and oxidative stress in $\beta$ cell of islet Langerhans in pancreas. C. papaya leaves aqueous extract in doses of $0.11 \mathrm{~g} / \mathrm{mL}$ and $0.22 \mathrm{~g} / 2 \mathrm{~mL}$ has antidiabetic, antihyperlipidaemic and antioxidant effect with protective effect on pancreas and other organs. C. papaya could be used as prophylaxis from diabetes as well as treatment to its complications, through its antioxidant activities. 


\section{Acknowledgment}

The authors would like to express their great thanks to Dr. Mohamed Metwally, Professor of Pathology, Faculty of Veterinary Medicine, Zagazig University for his great help in performing the histopathological study.

\section{Conflict of interest}

The authors have no conflict of interest to declare.

\section{References}

[1] Sacks, D.B.; Bruns, D.E.; Goldstein, D.E.; Maclaren, N.K.; McDonald, J.M. and Parrott, M. (2002): Guidelines and recommendations for laboratory analysis in the diagnosis and management of diabetes mellitus. Clin Chem, 48(3): 436-472.

[2] Ladan, M.J.; Umar, R.A.; Hassan, S.W. and Shehu, B. (2007): Glycemic status and lipid profiles of diabetes in Sokoto, Nigeria. Asian J Biochem, 2(3): 183-187.

[3] Guzman, J.R.; Lyra, R.; Aguilar-Salinas, C.A.; Cavalcanti, S.; Escaño, F.; Tambasia, M.; Duarte, E. and ALAD Consensus Group (2010): Treatment of type 2 diabetes in Latin America: a consensus statement by the medical associations of 17 Latin American countries. Latin American Diabetes Association. Rev Panam Salud Publica., 28(6): 463-471.

[4] Agbor, G.A.; Kuate, D. and Oben, J.E. (2007): Medicinal plants can be good source of antioxidants: Care study in Cameroon. Pakistan J Biol Sci, 10(4):537544.

[5] Manjusha, N.; Agrawal, N.; Nitesh, N. and Pankay, G. (2012): Effect of petroleum ether extract of Sesbaniasesban (Merr) roots in streptozotocin-induced diabetes in mice. Asian Pac J Trop Biomed, 2(3): S1254-S1260.

[6] Sobia, k.; Javaid, M.; Sheeraz, A.M.; Rehmatullah, Q.; Hina, G.; Iram, B.; Pervaiz, A.; Farhana, A.; Nyla, J. and Gulfraz, M. (2016): Assessments of phytochemicals and hypoglycemic activity of leaves extracts of Carica papaya in diabetic mice. Int J Pharm Sci Res, 7(9): 3658-3665.
[7] Barine, I.N.; Nwibani, M.N. and Michael, O.M. (2009): The effect of aqueous extract of Carica papaya leaves on liver enzymes and blood cell counts of normal albino rats. Int $\mathrm{J}$ Biol Chem Sci, 3(3):561-566.

[8] Al-Enazi, M.M. (2014): Combined therapy of rutin and silymarin has more protective effects on streptozotocininduced oxidative stress in rats. J App Pharm Sci, 4 (1): 21-28

[9] Coles, E.H. (1986): Veterinary Clinical Pathology, $4^{\text {th }}$ ed. W.B. Saunders Company, Philadelphia, London.

[10] Bancroft, J.D.; Steven, A. and Turner, D.R. (1996): Theory and Practice of Histological Technique, $4^{\text {th }}$ ed., Churchil, Living Stone, New York, London, Sanfrancisco, Philadelphia.

[11] Ghavamizadeh, M. and Mirzaei, A. (2015): Antioxidant activity and hepatoprotective potential of Artemisia aucheri in rat. Indian J Sci and Technol, $8(12): 1-8$.

[12] Trinder, P. (1969): Determination of glucose in blood using glucose oxidase with an alternative oxygen acceptor. Ann Clin Biochem, 6(1): 24-33.

[13] Mercodia, A.B. (2008): Mercodia Insulin ELISA kits insert. Mercodia AB, Sylveniusgatan 8A, SE-754 50 Uppsala, Sweden.

[14] Hurst, P. (1987): Effect of anticoagulant on fractosamine determination. Clin Chem, 33(10): 1947.

[15] Fossati, P. and Principe, L. (1982): Serum triglycerides determined colorimetrically with an enzyme that produces hydrogen peroxide. Clin Chem, 28(10): 2077-2080.

[16] Friedewald, W.T.; Levy, R.I. and Fredrickson, D.S. (1972): Estimation of the concentration of low-density lipoprotein cholesterol in plasma without use of the preparative ultracentrifuge. Clin Chem, 18(6): 499-502.

[17] Aebi, H. (1984): Catalase in Vitro in: Packer L (Ed.) Methods in Enzymology. Academic Press, San Diego121-126. 
[18] Ohkawa, H.; Ohishi, I. and Yagi, K. (1979): Assay for lipid peroxides in animal tissues by thiobarbitturic acid reaction. Anal Biochem, 95(2): 351-358.

[19] Tamhans, C. and Dunlop, D. (2000): Statistics and Data Analysis: From Elementary to Intermediate. Upper Saddle River, USA.

[20] Schmidt, B.; Ribnicky, D.M.; Poulev, A.; Logendra, S.; Cefalu, W.T. and Raskin, I. (2008): A natural history of botanical therapeutics. Metabolism, 57(7 Suppl 1): S3-9.

[21] Modak, M.; Dixit, P.; Londhe, J.; Ghaskadbi, S. and Devasagayam, T.P. (2007): Indian herbs and herbal drugs used for the treatment of diabetes. J Clin Biochem Nutr, 40(3): 163-173.

[22] Venkateshwarlu, E.; Dileep, P.; Rakesh, K.R. and Sandhya, P. (2013): Evaluation of antidiabetic activity of Carica papaya seeds on streptozotocin induced type II diabetic rats. J Adv Sci Res, 4(2): 38-41.

[23] Kennedy, L. and Baynes, J.W. (1984): Non-enzymatic glycosylation and the chronic complications of diabetes: an overview. Diabetologia, 26(2):93-98.

[24] Kumar, A.S.; Priti, T.; Swayam, P.S.; Rohit, S.; Akansha, M.; Neha, R.; Sukanya, P.; Akhilesh, K.T.; Tadigoppula, N.; Mahendra, N.S. and Vija, L. (2014): Antihyperglycaemic and antidyslipidemic activities in ethyl acetate fraction of fruits of Marine mangrove Xylocarpus moluccensis. International Journal of Pharmacy and Pharmaceutical Sciences, 6(1): 809-826.

[25] Amat-Alrazaq, A.A. (2009): Study on the potential antidiabetic effects of trigonelline alone and with vildagliptin in type-2 diabetic model in rats. MSc, Thesis, Pharmacology and Toxicology Department, Faculty of Pharmacy, Cairo University.

[26] Henderson, A.E. (2007): Can the consumption of fruits containing anthocyanins reduce the risk of developing type 2 diabetes. MSc Thesis, Food Science and Human Nutrition
Department, Faculty of Science, University of Maine May, England.

[27] WHO (2012): Traditional medicine strategy: 2002-2005. World Health Organization press, 1-6.

[28] Hamden, K.; Jaouadi, B.; Zara, N.; Rebai, T.; Carreau, S. and Elfeki, A. (2011): Inhibitory effects of estrogens on digestive enzymes, insulin deficiency, and pancreas toxicity in diabetic rats. $\mathbf{J}$ Physiol Biochem, 67(1):121-128.

[29] Gupta, R.; Sharma, A.K.; Sharma, M.C. and Gupta, R.S. (2012): Antioxidant activity and protection of pancreatic $\beta$ cells by Embelin in streptozotocininduced diabetes. J Diabetes, 4(3): 248256.

[30] Hii, C.S. and Howell, S.L. (1985): Effects of flavonoids on insulin secretion and $45 \mathrm{Ca} 2+$ handling in rat islets of Langerhans. J Endocrinol, 107(1):1-8.

[31] Ahmed, O.; Abdel Moneim, A.; Abul Yazid, I. and Mahmoud, A. (2010): Antihyperglycemic, antihyperlipidemic and antioxidant effects and the probable mechanisms of action of Ruta graveolens infusion and rutin in nicotinamidestreptozotocin-induced diabetic rats. Diabet Croat, 39(1):15-35.

[32] Juarez-Rojop, I.E.; Juan, C.D.; Jorge, L.B.; Pedro, H.T.; Arturo, R.; Hidemi, A.M.; Teresa, R.F. and Deysi, Y.B. (2012): Hypoglycemic effect of Carica papaya leaves in streptozotocin-induced diabetic rats. BMC Complement Alter Med, 12: 236.

[33] Pepato, M.T.; Baviera, A.M.; Vendramini, R.C. and Brunetti, I.L. (2004): Evaluation of toxicity after onemonth treatment with Bauhinia forficata decoction in streptozotocin-induced diabetic rats. BMC Complement Alter Med, 4:7.

[34] Kondeti, V.K.; Badri, K.R.; Maddirala, D.R.; Thur, S.K.; Fatima, S.S.; Kasetti, R.B. and Rao, C.A. (2010): Effect of Pterocarpus santalinus bark, on blood glucose, serum lipids, plasma insulin and 
hepatic carbohydrate metabolic enzymes in streptozotocin-induced diabetic rats. Food Chem Toxicol, 48(5):1281-1287.

[35] Cumaoğlu, A.; Ari, N.; Kartal, M. and Karasu, Ç. (2011): Polyphenolic extracts from Olea europea L. protect against cytokine-induced $\beta$-cell damage through maintenance of redox homeostasis. Rejuvenation Res, 14(3):325-334.

[36] Packer, L.; Rosen, P.; Tritschler, H.; King, G.L. and Azzi, A. (2000): Antioxidants and Diabetes Management. 1st Ed., New York: Marcel Dekker, 303$320 \mathrm{p}$.

[37] Wilcox, L.J.; Borradaile, M.N. and Huff, M.W. (2000): Antiatherogenic properties of naringerin, a citrusflavonoids. Card Drug Rev, 17(2): 160-178.

[38] Kannel, W.B. and McGee, D.L. (1979): Diabetes and glucose tolerance as risk factors for cardiovascular disease: the framingham study. Diab Care, 2(2):120126.

[39] Akula, A.; Kota, M.K.; Gopisetty, S.G.; Chitrapu, R.V.; Kalagara, M.; Kalagara, S.; Veeravalli, K.K. and Gomedhikam, J.P. (2003): Biochemical, histological and echocardiographic changes during experimental cardiomyopathy in STZinduced diabetic rats. Pharmacol Res, 48(5): 429-435.

[40] Dennis, A.; Udosen, E.O.; Edet, E.E.; Asanga, E.E. and Mbakwe, I.E. (2015): Lipid profile status of streptozotocin induced diabetic rats treated with ethanolic leaf extract of Solenostemon monostachyus. J Med Plants Res, 9(8): 289-293.

[41] Knekt, P.; Kumpulainen, J.; Jarvinen, R.; Rissanen, H.; Heliövaara, M.; Reunanen, A.; Hakulinen, T. and Aromaa, A. (2002): Flavonoid intake and risk of chronic diseases. The Amer J Clin Nut, 76(3): 560-568.

[42] Miyake, Y.; Yamamoto, K.; Tsujihara, N. and Osawa, T. (1998): Protective effects of lemon flavonoids on oxidative stress in diabetic rats. Lipids, 33(7): 689-695.
[43] Bok, S.H.; Lee, S.H.; Park, Y.B.; Bae, K.H.; Son, K.H.; Jeong, T.S. and Choi, M.S. (1999): Plasma and hepatic cholesterol and hepatic activities of 3hydroxy-3-methyl-glutaryl-CoA

reductase and acyl CoA: cholesterol transferase are lower in rats fed citrus peel extractor a mixture of citrus bioflavonoids. J Nut, 129(6): 1182-1185.

[44] Halliwell, B. and Gutteridge, J.M. (1989): Free Radicals in Biology and Medicine, 2nd Ed, UK: Oxford University Press, Oxford, 200-231 p.

[45] Wilson, R.L. (1998): Free Radicals and Tissue Damage, Mechanistic Evidence from Radiation Studies, in Biochemical Mechanisms of Liver Injury New York, NY, USA: Academic Press, 123-125.

[46] Jacqueline, M.S.; Jongsoon, L. and Paul, F.P. (1997): Tumor necrosis factoralpha-induced insulin resistance in 3T3$\mathrm{L} 1$ adipocytes is accompanied by a loss of insulin receptor substrate-1 and GLUT4 expression without a loss of insulin receptor-mediated signal transduction. J Bio Chem, 272 (2): 971976.

[47] Buttke, T.M. and Sandstorm, P.A. (1994): Oxidative stress as a mediator of apoptosis. Immunol Today, 15(1), 7-10.

[48] Amin, K.A.; Awad, E.M. and Nagy, M.A.(2011): Effects of panax quinquefolium on streptozotocin-induced diabetic rats: role of $\mathrm{C}$-peptide, nitric oxide and oxidative stress. Int J Clin Exp Med, 4(2):136-147.

[49] Abdolfathi, A.A.; Mohajeri, D.; Rezaie, A. and Nazeri, M. (2012): 3 EvidenceBased Compl and Alter Med, vol. 2012, Article ID 740671, 10 pages

[50] Adewole, S.O. and Caxton-Martins, E.A. (2006): Morphological changes and hypoglycemic effects of Annona Muricata Linn. (Annonaceae) leaf aqueous extract on pancreatic $\beta$-cells of streptozotocin-treated diabetic rats. African J of Biom Res, 9: 173 - 187.

[51] Durdi, Q. and Timur, R. (2007): Catalase (antioxidant enzyme) activity in 
streptozotocin-induced diabetic rats. Int J Diabetes Metab, 15: 22-24.

[52] Gouado, I.; Schweigert, F.J.; Ejoh, R.A.; Tchouanguep, M.F. and Camp, J.V. (2007): Systemic levels of carotenoids from mangoes and papaya consumed in three forms (juice, fresh and dry slice). Eur J Clin Nutr, 61(10):11801188.

[53] Amer, J.; Goldfarb, A.; Rachmilewitz, E.A. and Fibach, E. (2008): Fermented papaya preparation as redox regulator in blood cells of beta-thalassemic mice and patients. Phytother Res, 22(6):820-828.

[54] Anuar, N.S.; Zahari, S.S.; Taib, I.A. and Rahman M.T. (2008): Effect of green and ripe Carica papaya epicarp extracts on wound healing and during pregnancy. Food Chem Toxicol,46(7):2384-2389.

[55] Looze, Y.; Boussard, P.; Huet, J.; Vandenbussche, G.; Raussens, V. and Wintjens, R. (2009): Purification and characterization of a wound-inducible thaumatin-like protein from the latex of Carica papaya. Phytochemistry,70(8):970-978.

[56] Osato, J.A.; Santiago, L.A.; Mori, A. and Horitsu, H. (1995): Antioxidant defenses of Immun' Age. Mag Resonance in Med, 6: 306-308.
[57] Sadek, M.K. (2012): Antioxidant and immune-stimmulant effect of Carica papaya Linn. aqueous extract in acrylamide intoxicated rats. Acta Inform Med J, 20(3): 180-185.

[58] Sikar, A.A.; Ozdogan, H.K. and Bilen, N. (2012): Nitric oxide and malondialdehyde levels in plasma and tissue of psoriasis patients. J Eur Acad Dermatol Venereol, 26 (7):833 -837.

[59] Bhutia, Y.; Ghosh, A.; Sherpa, M.L.; Pal, R. and Mohanta, P.K. (2011): Serum malondialdehyde level: Surrogate stress marker in the Sikkimese diabetics. J Nat Sci, Bio, Med, 2(1):107-112.

[60] Giannoukakis, N.; Rudert, W.A.; Trucco, M. and Robbins, P.D. (2000): Protection of human islets from the effects of interleukin-1beta by adenoviral gene transfer of an Ikappa B repressor. J Bio Chem, 275(47):36509-36513.

[61] Man, D.; Tie, H.; Shunan, L.; Jing, Z.; Yixiao, M. and Jiaye, M. (2013): Hepatoprotective effect of the flavonoid fraction isolated from the flower of Inula britannica against D-galactosamineinduced hepatic injury. Mol Med Rep, 7(6): 1919-1923.

[62] Halliwell, B. (1997): Antioxidants and human disease: A general introduction. Nutrition Reviews, 55(1):S44-S49. 
الملخص العربي

$$
\begin{aligned}
& \text { دراسات باثولوجيه إكلينيكية على تأثير نبات الباباز على سكر الدم المستحث تجريبياً فى الفئران } \\
& \text { محمد عبد العظيم هاثم ، شيماء احمد عبد الفتاح إسماعيل و بسمة حمح عوض الليثي }
\end{aligned}
$$

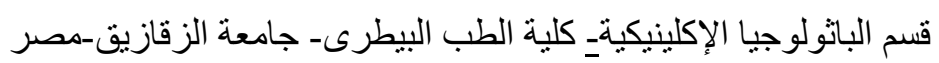

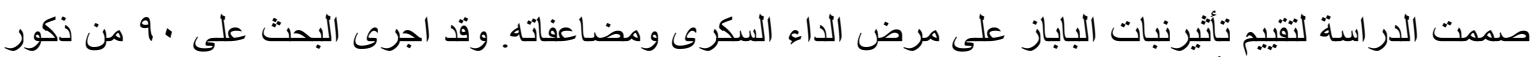

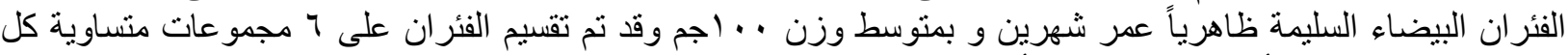

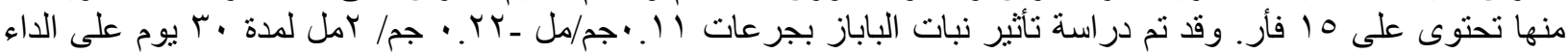

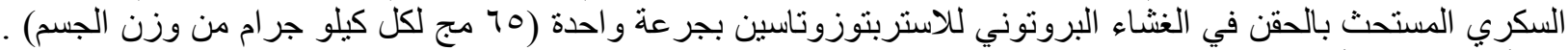

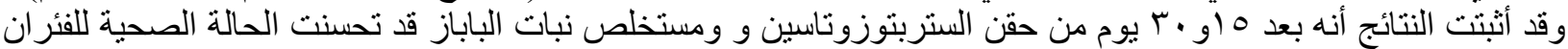

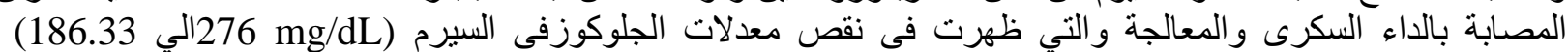

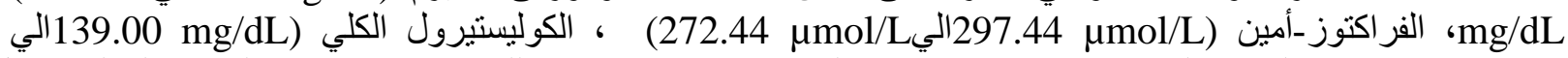
(الدهون الثلاثية (121.46 mg/dL ) (179.34 mg/dL) ، الليبوبروتين منخفض الكثافة، الكوليستيرول

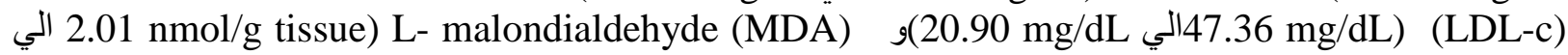

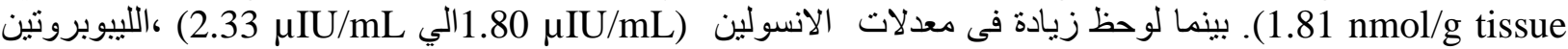

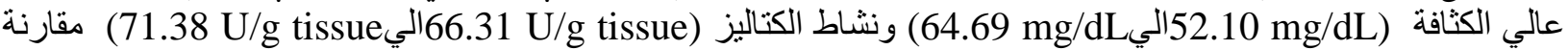

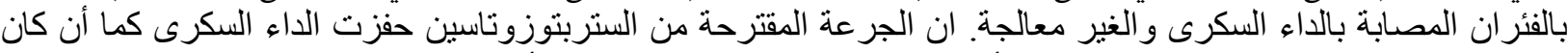

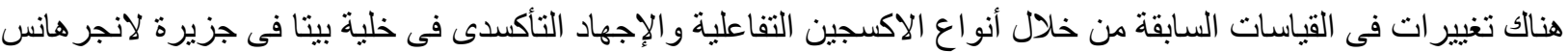

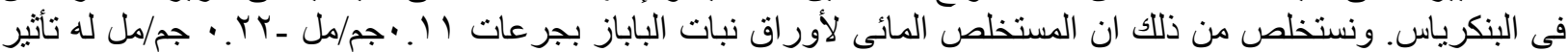

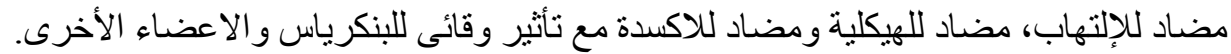

